Journal of Advanced Research in Fluid Mechanics and Thermal Sciences

\title{
Design and Preliminary Testing of a Small-Scale Throatless Fixed-Bed Downdraft Gasifier Fueled With Sengon Wood Block
}

\author{
Samsudin Anis ${ }^{1,}{ }^{*}$, Benny Nugroho ${ }^{1}$, Adhi Kusumastuti ${ }^{2}$ \\ Department of Mechanical Engineering, Universitas Negeri Semarang, Kampus Sekaran, Gunungpati, 50229 Semarang, Indonesia \\ Faculty of Engineering, Universitas Negeri Semarang, Kampus Sekaran, Gunungpati, 50229 Semarang, Indonesia
}

Article history:

Received 24 October 2020

Received in revised form 17 December 2020

Accepted 21 December 2020

Available online 28 January 2021

\section{Keywords:}

Design; preliminary testing; fixed-bed; downdraft gasifier

\begin{abstract}
The aims of this study are to design and to find out the performance of a throatless fixed bed downdraft gasifier. This gasifier was used to convert sengon wood block from furniture waste into gas fuel called producer gas that is beneficial for green energy production to substitute the fossil fuel. The gasifier was designed to have a thermal power of $30 \mathrm{~kW}_{\text {th }}$ with double wall/tube and air as the gasifying medium. Sengon wood block with a size of about $5-8 \mathrm{~m}^{3}$ and moisture content of $10 \%$ was used as the feedstock. The gasifier was tested at various equivalence ratio ranging from 0.18 to 0.28 . In this work, the performance of the gasifier was evaluated by observing the temperature profile, flame condition, fuel consumption rate, specific gasification rate, and the amount of solid residue. The results showed that the designed gasifier had a diameter of $22 \mathrm{~cm}$ for the inner tube and $32 \mathrm{~cm}$ for the outer tube with a gasifier height of $100 \mathrm{~cm}$. It was found that the equivalence ratio highly influenced the gasifier performance. Fuel consumption rate and specific gasification rate increased with the increase of equivalence ratio. In the meantime, the amount of solid residue appeared to be reduced because of high gasification rate. Under the condition investigated, the best gasifier performance was obtained at an equivalence ratio of 0.28 indicated by the stability of the flame during gasification process that is in accordance to the gasifier design parameters.
\end{abstract}

\section{Introduction}

Conventional energy or fossil energy is still the main energy source used by both society and industry in Indonesia. Data shows that in 2019 Indonesia has a large proven oil reserve of 3.7 billion barrels or $0.3 \%$ of the proven world oil reserves [1]. However, energy demand and consumption of fossil fuels especially petroleum, natural gas and coal in Indonesia from year to year increase along with the economic and population growth as well as industrial development. Based on data in the

\footnotetext{
* Corresponding author.

E-mail address: samsudin_anis@mail.unnes.ac.id
}

https://doi.org/10.37934/arfmts.80.1.112 
Indonesia Energy Outlook (IEO) 2019 [1], Indonesia is one of the countries with a high growth in energy consumption in the world at $7 \%$ per year. Data shows that industry is the sector with the highest energy consumption of $50 \%$. The energy consumption in the transportation, household and commercial sectors was $34 \%, 12 \%$ and $4 \%$, respectively. In addition, almost $95 \%$ of the energy consumption is supplied from fossil fuels, of which $50 \%$ uses fuel oil. The continued use of fossil fuels will result in the depletion of fossil fuels, which in turn has an impact on the fuel scarcity.

One of the best solutions to overcome the scarcity of fossil fuels is to provide fuel from alternative energy sources. Alternative energy is environmentally friendly energy and can be renewed by utilizing natural materials or biomass waste. Energy from woody biomass is the dominant energy source in rural communities. More than fifty percent of people in Indonesia still uses wood biomass that is burned directly as an energy source [2]. One of the potential biomass raw materials from wood waste is sengon wood. Sengon wood has a density of $320-640 \mathrm{~kg} / \mathrm{m}^{3}$ at a moisture content of $15 \%$, which is included in mild and moderately light wood [3]. Sengon wood is an original plant of Indonesia spread throughout the Indonesian region with a harvest age of approximately 7 years, which is relatively shorter than other types of wood. Data shows that in 2016, sengon wood production reached 2.56 million $\mathrm{m}^{3}$ [4], which could be the basis that sengon wood has great potential as a raw material for renewable energy.

It is known that utilization of woody biomass into energy through direct combustion is an inefficient process because a lot of heat energy is wasted. For this reason, better technology is needed to treat woody biomass waste. One of the technologies that can be applied to supply renewable energy from woody biomass is gasification. Biomass gasification is a series of chemical reactions of biomass components at high temperatures with limited air as gasifying medium to produce gases that generally contain $\mathrm{CO}, \mathrm{H}_{2}$ and $\mathrm{CH}_{4}$ [5]. Gasification is the best process for converting woody biomass to gas called producer gas compared to other processes such as pyrolysis and bio-chemical processes [5]. The advantage of the gasification process is not only that biomass feedstock can be obtained easily but also the combustion of gas produced is cleaner. In addition, among the various types of gasification reactors, downdraft fixed-bed gasifier is able to produce cleaner (tar-free) gases, easy to operate, and is suitable for small-scale application [6]. Application of fixed-bed gasifier for palm oil pyrolysis has been done [7]. In order to convert biomass into gas fuel using a downdraft gasifier, the main first step that needs to be done is to design a reactor as needed.

Some literature shows that there are several parameters that need to be considered in the downdraft gasifier design process such as gasifier capacity, gasification agent, type of biomass used, equivalence ratio, etc. [8-12]. This gives the impression that the downdraft gasifier design processes are unique and tend to be specific. Therefore, it is important to design a downdraft gasifier for biomass conversion that is suitable for sengon wood gasification.

Based on the above description, it can be identified that there is still room for further research on wood biomass gasification using a downdraft gasifier. So that, the objectives of this study are to design and to find out the performance of the designed gasifier in the form of temperature profiles, fuel consumption rates, specific gasification rates, the amount of solid residues, and the flames of the producer gas generated. In addition, a throatless fixed bed downdraft gasifier was chosen in this work. 


\section{Design and Experimental Methods}

\subsection{Design of Downdraft Gasifier}

In this work, the designed biomass gasifier was a throatless fixed-bed downdraft gasifier. The gasifier reactor was designed using mathematical formulas and experimental data from the literature based on the following considerations

a. The capacity of the gasifier or thermal power output and the gasifying agent were determined;

b. The type of biomass used and the gasifier efficiency were selected

The internal diameter of the gasifier (D) was determined by the required thermal power output, while the height of the gasifier $(\mathrm{H})$ was determined by the required time for one batch operation. In this work, thermal power of the gasifier $(P)$ of $30 \mathrm{~kW}$ th or $108 \mathrm{MJ} / \mathrm{h}$ was applied. Eq. (1)-(4) were used for the determination of the internal diameter, height, and required airflow rate of the gasifier $[9,13]$.

$D=\sqrt{\frac{1.27 \times F C R}{S G R}}$

where SGR is the specific gasification rate $\left(\mathrm{kg} / \mathrm{m}^{2} \mathrm{~h}\right)$. Commonly, SGR for gasifier design is in the range of $110-210 \mathrm{~kg} / \mathrm{m}^{2} \mathrm{~h}$ [9] in which SGR of $210 \mathrm{~kg} / \mathrm{m}^{2} \mathrm{~h}$ was selected. FCR is the fuel consumption rate $(\mathrm{kg} / \mathrm{h})$ calculated as follows

$F C R=\frac{P}{H H V \times \eta}$

where HHV is the higher heating value of biomass fuel $(\mathrm{MJ} / \mathrm{kg})$ and $\eta$ is the gasifier efficiency. The height of the gasifier can be determined as

$H=\frac{S G R \times t}{\rho_{f}}$

where $t$ is the duration time during gasifier operation (h) and $\rho_{f}$ is the density of biomass fuel $\left(\mathrm{kg} / \mathrm{m}^{3}\right)$. Finally, required airflow rate of the gasifier (AFR) can be calculated based on the following equation

$A F R=E R \times F C R \times S c$

where ER is the equivalence ratio and Sc is the air-fuel stoichiometric. In this study, ER of 0.28 and Sc of $5.22 \mathrm{~m}^{3}$ of air per $\mathrm{kg}$ of biomass were applied [14].

The throatless fixed-bed downdraft gasifier was fabricated in a local workshop according to the design. Double pipa reactor was constructed and the air between the two walls with a $50 \mathrm{~mm}$ gap acts as insulating material. The gasifier has opening on the top for feeding of the fuel. The grate can be dismantled easily for maintenance and cleaning purpose. 


\subsubsection{Experimental materials}

Sengon wood materials obtained from furniture industry waste were used in this study. Before used, the raw material was dried for two days in the sun until the average moisture content of woody biomass reaches about $10 \mathrm{wt} . \%$. The dry raw material was then cut into blocks with a size of $5-8 \mathrm{~cm}^{3}$. To start up the gasifier, wood charcoal was used as the fuel.

\subsubsection{Experimental apparatus}

Figure 1 shows the scheme of the experimental equipment. In this study, the designed gasification reactor that is a throatless fixed-bed downdraft gasifier was employed. There were four measurement points (T1, T2, T3, and T4) in the gasifier with a distance between points is $200 \mathrm{~mm}$. The first point was positioned at $125 \mathrm{~mm}$ above the grate. The measurement points were used to measure the changes of reaction temperature along the drying zone (T1) up to the reduction zone (T4). The temperatures at each point were measured using thermocouples and the measurement results were displayed with the aid of a thermometer reader. In this research, K-type thermocouples were used that can detect working temperatures in the range of $-200^{\circ} \mathrm{C}$ to $1300^{\circ} \mathrm{C}$. While the thermometer reader used was a Hylec thermometer reader with a working range of $50^{\circ} \mathrm{C}$ to $1300^{\circ} \mathrm{C}$. Air entering the gasifier was supplied by using a blower through a piping system that is equipped with an airflow velocity control valve. The blower used was a centrifugal blower with $150 \mathrm{~W}$ of power. Airflow velocity was measured using an anemometer. In addition, the system was also equipped with a camera to capture the flames of producer gas during gasification process.

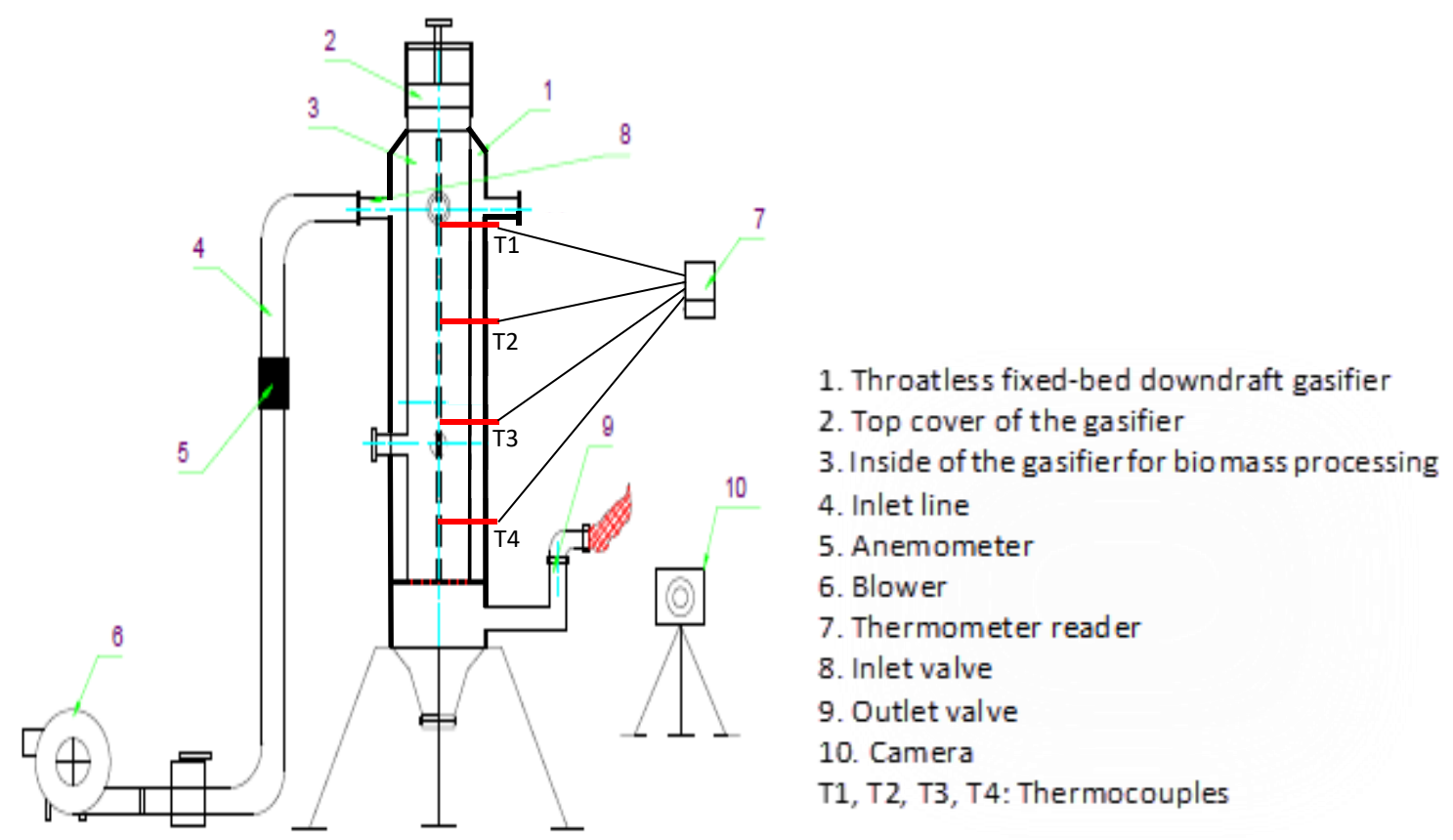

Fig. 1. Schematic diagram of the downdraft gasification experimental apparatus

\subsection{Experimental Procedure}

The research began by pouring around $2 \mathrm{~kg}$ of charcoal into the gasifier and burning it for startup process. After burning for about 15 minutes, about $4 \mathrm{~kg}$ of biomass feedstock was put into the gasifier for the first stage of gasification. Then the blower was turned on and the airflow 
velocity was adjusted through the inlet valve as needed at various equivalence ratios of $0.18,0.22$ and 0.28 . The next step is adding biomass feedstock every 30 minutes to ensure the gasification process could be run continuously. The total amount of raw materials in this study was limited to $12 \mathrm{~kg}$. During the process, temperature changes at each point were recorded every 10 minutes until the completion of the test, which is around 90 minutes.

In this study, the producer gas flame was observed by taking the flame picture in the outlet gas pipe. The flame picture on each experiments was captured using a camera. After the gasification process was completed of around 90 minutes, the fuel residue was taken and weighed. In addition, the biomass consumption rate (FCR), specific gasification rate (SGR), and the percentage of solid residues (SR) were then calculated based on Eq. (5)-(7). This was done for each variation of the equivalence ratio in this study. It should be noted that the biomass feedstock used is sengon wood in the form of blocks with a size of $5-8 \mathrm{~cm}^{3}$.

$$
\begin{aligned}
& F C R=\frac{m_{f}}{t} \\
& S G R=\frac{m_{f}}{A \times t} \\
& S R=\frac{m_{S R}}{m_{f}} \times 100 \%
\end{aligned}
$$

where $m_{f}$ and $m_{S R}$ are the total mass of biomass $(\mathrm{kg})$ and mass of solid residue $(\mathrm{kg})$, respectively. While $t$ and $A$ are the total gasification time (h) and cross section area of the reactor $\left(\mathrm{m}^{2}\right)$, respectively.

\section{Results and Discussion}

\subsection{Downdraft Gasifier Design}

Main information needed in designing the downdraft gasifier is provided in Table 1. Based on the input data given in Table 1, the main geometry and parameter of the designed gasifier were calculated according to Eq. (1)-(4) and the results are listed in Table 2.

\section{Table 1}

Input data used for gasifier design

\begin{tabular}{lll}
\hline Description & Value & Remark/reference \\
\hline Biomass feedstock & Sengon wood & Furniture waste \\
Biomass size & $5-8 \mathrm{~cm}^{3}$ & Cut block size \\
Higher heating value, HHV & $17.9 \mathrm{MJ} / \mathrm{kg}$ & Measured \\
Moisture content, MC & $11 \mathrm{wt} . \%$ & Measured \\
Bulk density, $\rho \mathrm{f}$ & $320 \mathrm{~kg} / \mathrm{m}^{3}$ & Measured \\
Gasifying medium & air & Designed \\
Air density, $\rho_{\mathrm{a}}$ & $1.25 \mathrm{~kg} / \mathrm{m}^{3}$ & Designed \\
Gasification operation duration, t & $1.5 \mathrm{~h}$ & Designed \\
Gasification efficiency, $\eta$ & $75 \%$ & Designed \\
Specific gasification rate, SGR & $210 \mathrm{~kg} / \mathrm{m}^{2} . \mathrm{h}$ & {$[7]$} \\
Equivalence ratio, ER & 0.28 & {$[13]$} \\
\hline
\end{tabular}


The experimental setup of throatless fixed-bed downdraft gasifier was built as shown in Figure 2. It consists of top cover for biomass feeding, inlet line for air from blower, reactor, combustion zone window, grate, outlet line for producer gas from reactor, ash-handling system, supporting frame, etc. All parts of the gasifier are made of mild steel material. The biomass is fed from the top cover into the reactor. During gasification process, biomass decomposition inside the gasifier can be monitored through combustion zone window. The producer gas generated comes out from the bottom that can be burned it at the flare port of outlet line. The remaining ash is collected in the ash container. Air blower of $150 \mathrm{~W}$ with variable airflow rates was used to provide sufficient quantity of air for combustion. Four air holes with $10 \mathrm{~mm}$ diameter were provided at 90ㅇ each.

Table 2

Geometry and parameter of the designed gasifier

\begin{tabular}{ll}
\hline Description & Value \\
\hline Inner diameter of inside reactor & $0.22 \mathrm{~m}$ \\
Inner diameter of outside reactor & $0.32 \mathrm{~m}$ \\
Height of reactor & $1 \mathrm{~m}$ \\
Airflow rate, AFR & $12 \mathrm{~m}^{3} / \mathrm{h}$ \\
Fuel Consumption Rate, FCR & $8 \mathrm{~kg} / \mathrm{h}$ \\
Power of gasifier, P & $30 \mathrm{~kW}$ th \\
\hline
\end{tabular}

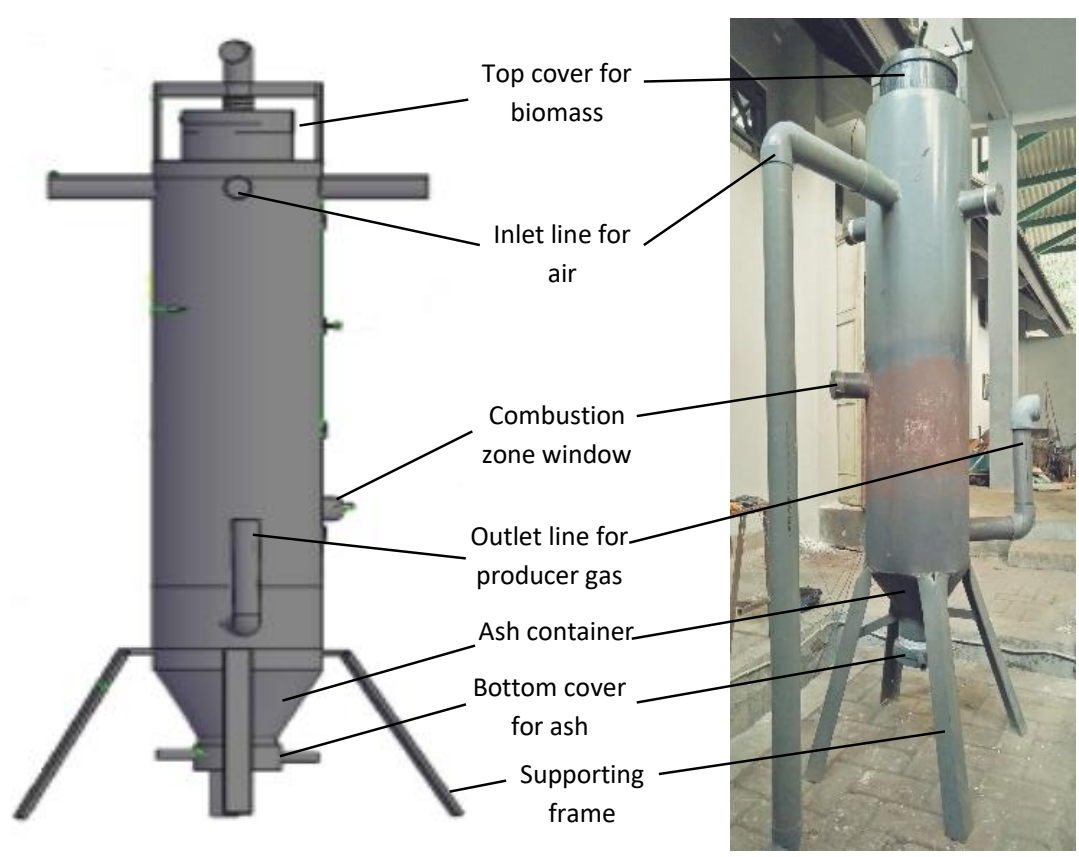

Fig. 2. Schematic and photograph of the throatless fixed-bed downdraft gasifier

\subsection{Gasification Temperature Profile}

In general, gasification involves four processes in producing the producer gas. These processes consist of a drying process, a pyrolysis process, an oxidation or combustion process, and a reduction process [5]. Each process has different reaction temperatures. Temperature is one of the important parameters in the overall biomass gasification process because it influences chemical reactions in converting biomass into mainly gases products $[8,15]$.

Figure 3 shows the temperature profile at measurement point 1 (T1). The temperature measured during the gasification process is in the range of $85^{\circ} \mathrm{C}$ to $178^{\circ} \mathrm{C}$. This indicates that at this 
point there was a process of evaporation of water content in biomass. In this zone, the biomass does not experience decomposition of chemical elements and only releases water content $[10,11]$. In general, the average gasification temperatures in the drying zone were found to be $130^{\circ} \mathrm{C}, 135^{\circ} \mathrm{C}$, and $154^{\circ} \mathrm{C}$ for ER $0.18,0.22$, and 0.28 , respectively. This shows that ER 0.28 generated higher drying zone temperature than the others. This is possible because the air supply at ER 0.28 is greater where the high heat energy generated in the combustion zone can be transferred to the drying zone. This condition allows the drying process of biomass to be faster, which in turn helps accelerate the decomposition of biomass into gas.

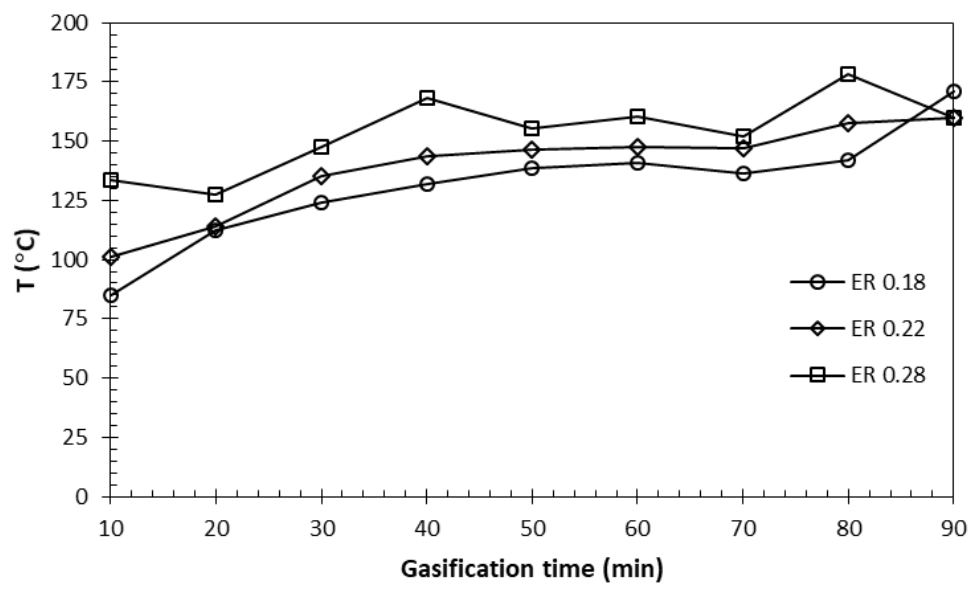

Fig. 3. Temperature profile at $\mathrm{T} 1$ at various equivalence ratio

Figure 4 shows the gasification temperature evolution at measurement point 2 (T2). The gasification temperatures were in the range of $94^{\circ} \mathrm{C}$ to $213^{\circ} \mathrm{C}$, meaning that the drying process of biomass still occurs in this zone. As in the $\mathrm{T} 1$ condition, at $\mathrm{T} 2$ also provides a similar temperature profile trend where ER 0.28 produces the highest temperature. The high heat energy transferred from pyrolysis or combustion of biomass into drying zone could be achieved at higher ER.

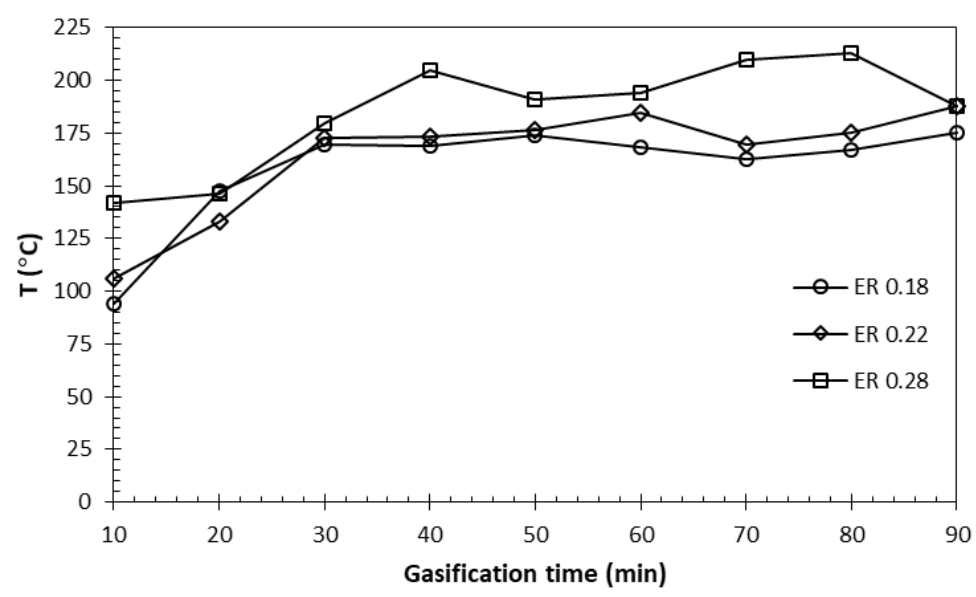

Fig. 4. Temperature profile at $\mathrm{T} 2$ at various equivalence ratio

In the T2 zone there is an increase in temperature so that the wood biomass with a lower moisture content is further heated which will then decompose into tar, gas and other products when it enters the pyrolysis zone. In the pyrolysis zone, the heating rate will tend to increase gradually with increasing temperature. The process of releasing gas in biomass mainly occurs at temperatures above $200^{\circ} \mathrm{C}$ [5]. In general, pyrolysis products consist of three types, namely gas 
$\left(\mathrm{H}_{2}, \mathrm{CO}, \mathrm{CO}_{2}, \mathrm{H}_{2} \mathrm{O}\right.$, and $\left.\mathrm{CH}_{4}\right)$, tar, and charcoal [5]. In the pyrolysis zone, the following reactions generally occur

$\mathrm{C}_{\mathrm{n}} \mathrm{H}_{\mathrm{m}} \mathrm{O}_{\mathrm{p}}$ (biomass) $\stackrel{\text { heat }}{\longrightarrow}$ Igas $+\mathrm{C}_{\mathrm{q}} \mathrm{H}_{\mathrm{r}} \mathrm{O}_{\mathrm{s}}+\mathrm{H}_{2} \mathrm{O}+$ char

where $n, m$, and $p$ have higher values than $q, r$, and $s$.

Figure 5 shows the gasification temperature evolution at T3 point, which is an oxidation zone with a temperature range between $710^{\circ} \mathrm{C}$ to $1080^{\circ} \mathrm{C}$. In this study, the highest temperature was obtained in this zone during sengon wood block gasification process. The data showed that the average temperature of the oxidation zone were $847^{\circ} \mathrm{C}, 894^{\circ} \mathrm{C}$, and $912^{\circ} \mathrm{C}$ for ER $0.18,0.22$, and 0.28 , respectively. The high average temperature of the oxidation zone at ER 0.28 is mainly due to the relatively high airflow rate supplied. This has an effect on the biomass decomposition process where some of the biomass raw materials are gasified and are partially burned to supply the heat energy needed in the biomass drying and pyrolysis processes.

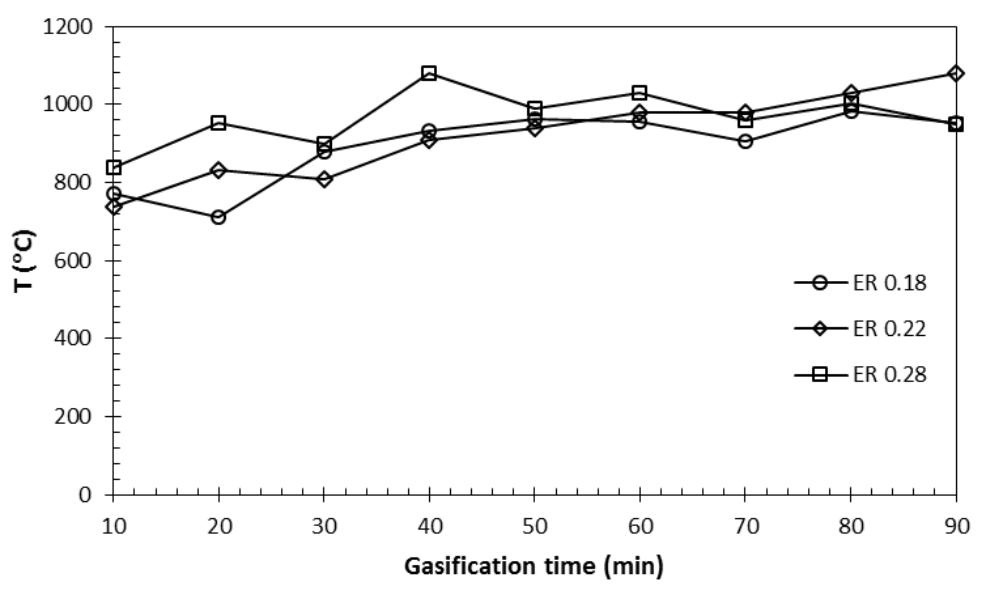

Fig. 5. Temperature profile at $\mathrm{T} 3$ at various equivalence ratio

The oxidation process in this T3 zone is very important because it produces the heat energy needed for ensuring all reactions could be occurred during the gasification process $[12,13]$. This process depends on the supply and distribution of air entering the gasifier. The higher the airflow rate, the faster the combustion process, which affects the temperature distribution within the gasifier. Chemical reactions in this zone are in the form of partial oxidation and total oxidation as follows $[5,10,11]$

Partial oxidation

$C+\frac{1}{2} \mathrm{O}_{2} \rightarrow C O-110 \mathrm{~kJ} / \mathrm{mol}$

Total oxidation

$\mathrm{C}+\mathrm{O}_{2} \rightarrow \mathrm{CO}_{2}-394 \mathrm{~kJ} / \mathrm{mol}$ 
Figure 6 shows the gasification temperature evolution in T4 zone, which is a reduction zone with temperatures ranging from $333^{\circ} \mathrm{C}$ to $687^{\circ} \mathrm{C}$. The reduction zone is a zone where the main reaction of carbon or charcoal gasification occurs into gas products. Several reactions occurred in this zone including Bouduard, water gas, water gas shift, or methane reactions, are influenced by temperature and pressure. This result is also comparable to the use of low rank coal as feedstock where better gasification process occurs at temperatures around $700^{\circ} \mathrm{C}[16]$.

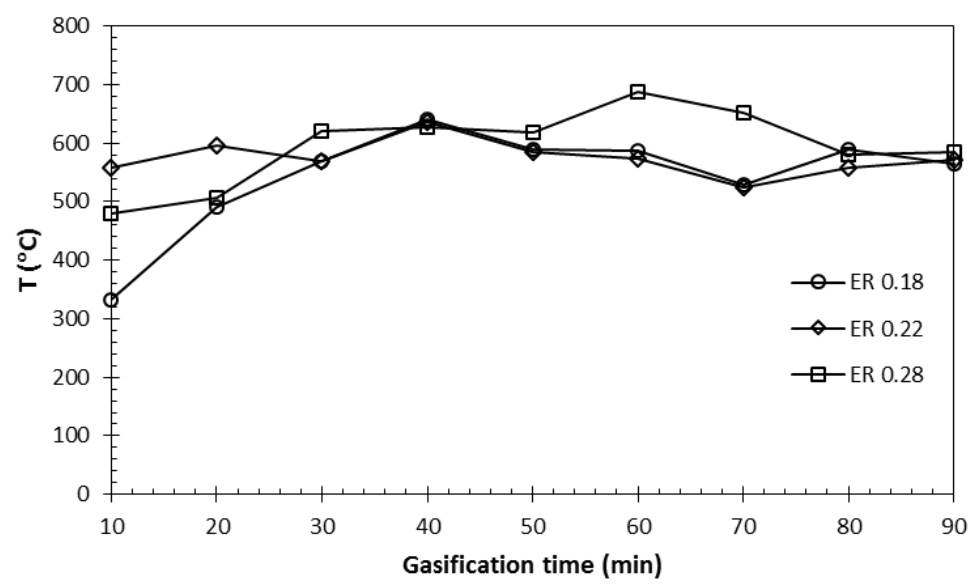

Fig. 6. Temperature profile at $\mathrm{T} 4$ at various equivalence ratio

\subsection{Flame of Producer Gas}

The flame of the burned producer gas is one of the indicators of gasification process. The composition of producer gas is influenced by the characteristics of biomass used and the amount of air supplied. Figure 7 shows photographs of the flame of producer gas produced during sengon wood block gasification process at various equivalence ratios.

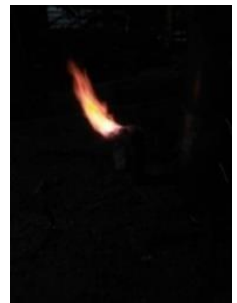

(a)

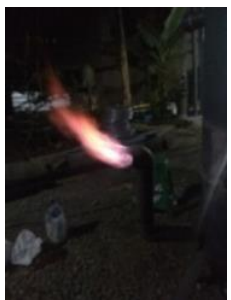

(b)

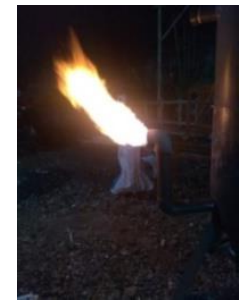

(c)

Fig. 7. Photographs of producer gas flame at: (a) ER 0.18, (b) ER 0.22, and (c) ER 0.28

The figure shows that the producer gas flame at ER 0.18 was predominantly red and shorter. In addition, the flame is unstable which indicates low quantity and quality of producer gas. Whereas at ER 0.22 , the producer gas flame was yellowish red and relatively stable, which indicates that there is a slight increase in the quantity and quality of producer gas. Better result was obtained at ER 0.28 where the producer gas flame was predominantly yellow, slightly bluish and longer. In this condition, the flame is very stable that characterizes the high quantity and quality of the producer gas. A blue flame indicates a high flammable gas content and clean that allows gas combustion to occur under stoichiometric condition. 


\subsection{Fuel Consumption Rate, Specific Gasification Rate and Solid Residue}

Figure 8 shows biomass consumption rate (FCR), specific gasification rate (SGR), and percentage of solid residue (SR) as a function of equivalence ratio (ER). These parameters are generally used in assessing the performance of the gasifier as a preliminary testing process because the measurement technique is relatively simple. As shown in the figure, both FCR and SGR increased as the increase of ER. This phenomenon is also reported in previous studies $[17,18]$. The FCR and SGR increased of about $30 \%-33 \%$ from ER 0.18 to ER 0.28 . It should be noted that the measured FCR and SGR values at ER of 0.28 are close to the design values of around $94 \%$ and $85 \%$, respectively. These slight differences are possible because several design parameters are assumed as recommended in previous studies. The homogeneity of the composition of the compounds and size of the raw materials are other challenges that need special attention.

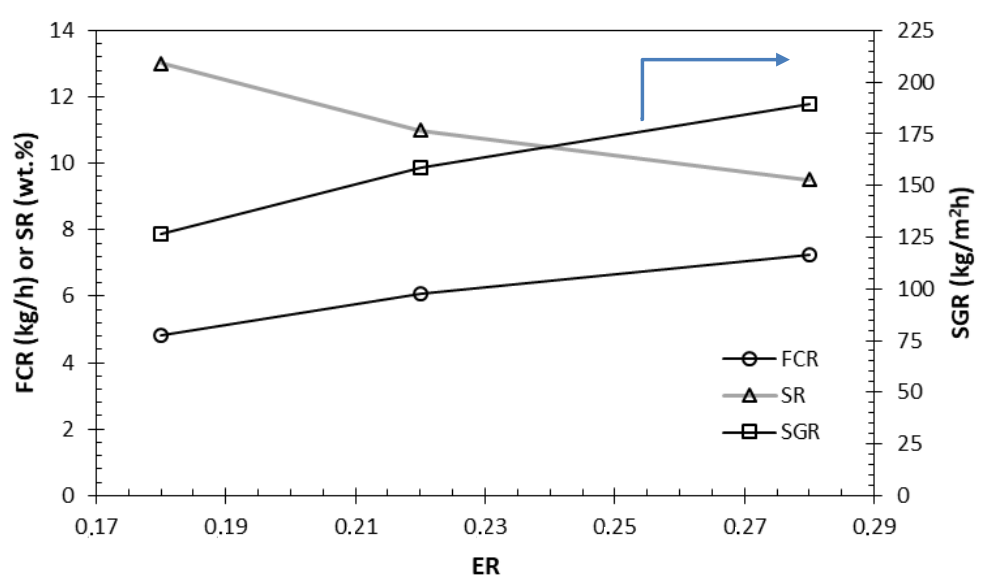

Fig. 8. Fuel consumption rate, specific gasification rate, and percentage of solid residue at various equivalence ratio

The percentage of solid residues is also depicted in Figure 8. The residues in this study refer to the residual solids such as ash and charcoal particles produced from biomass gasification process. The amount of solid residues is influenced by the conditions of biomass combustion reaction and charcoal reduction reaction that occurs during the gasification process. As shown, SR decreased as the increase of ER under the investigated condition. It was found that SR decreased by about 1.4 times when the ER was increased from 0.18 to 0.28 . The high amount of solid residue at low ER is caused by insufficient air supply into the reactor to convert the biomass into gaseous products. So that a higher air supply is needed to ensure the gasification process can take place properly. The pyrolysis zone is the main zone for charcoal formation process. Then, part of charcoal will be burned in the oxidation zone and partially will be gasified in the reduction zone as shown in Eq. (9)(10). The remaining unburned and unconverted charcoals accumulate with ash at the bottom of the reactor.

\section{Conclusions}

Design and preliminary performance test of downdraft gasifier for gasification of sengon wood blocks have been carried out. It is a throatless fixed bed downdraft gasifier with a thermal power of $30 \mathrm{~kW}_{\mathrm{th}}$, inner diameter of $22 \mathrm{~cm}$, and height of $100 \mathrm{~cm}$. A double pipe reactor model was constructed from mild steel material. The air between the two walls serves as the insulation material. The gasifier performance was highly influenced by the equivalence ratio. As expected, 
equivalence ratio of 0.28 was found to be the best condition where it not only produced the least solid residues but also provided the measured fuel consumption and specific gasification rates close to the design values. Furthermore, this condition also produced stable flame of producer gas during the gasification process.

\section{Acknowledgements}

The authors gratefully acknowledge the Applied Research Grant (No. 87.18.3/UN37/PPK.3.1/2019) awarded by the Directorate of Research and Community Service (DRPM) of the Directorate General of Research and Development Strengthening, Ministry of Research, Technology and Higher Education of the Republic of Indonesia to carry out this work.

\section{References}

[1] M. P. Saleh Abdurrahman, Walujanyo. "Indonesia Energy Outlook 2019." Jakarta: National Energy Council (2019).

[2] S. S. E. Nasional. "Bahan Bakar Utama untuk Memasak." Jakarta: Biro Pusat Statistik (2017).

[3] Krisnawati, Haruni, Eveliina Varis, M. H. Kallio, and Markku Kanninen. Paraserianthes falcataria (L.) Nielsen: ecology, silviculture and productivity. CIFOR, 2011.

[4] S.-d. o. F. Statistics. "Statistics of Forestry Production." Jakarta: Biro Pusat Statistik (2017).

[5] Basu, Prabir. Biomass gasification and pyrolysis: practical design and theory. Academic press, 2010.

[6] Antolini, Daniele, Snehesh Shivananda Ail, Francesco Patuzzi, Maurizio Grigiante, and Marco Baratieri. "Experimental investigations of air-CO2 biomass gasification in reversed downdraft gasifier." Fuel 253 (2019): 1473-1481. https://doi.org/10.1016/j.fuel.2019.05.116

[7] Isa, Khairuddin Md, L. J. Ying, Saiful Azhar Saad, Farizul Hafiz Kasim, and M. A. A. Rahim. "Pyrolysis of oil palm fronds in a fixed bed reactor and optimisation of bio-oil using Box-Behnken Design." Journal of Advanced Research in Fluid Mechanics and Thermal Sciences 27, no. 1 (2016): 12-18.

[8] Sutar, Kailasnath B., Sangeeta Kohli, and M. R. Ravi. "Design, development and testing of small downdraft gasifiers for domestic cookstoves." Energy 124 (2017): 447-460.

https://doi.org/10.1016/i.energy.2017.02.076

[9] Belonio, Alexis T. "Rice husk gas stove handbook." Appropriate Technology Center. Department of Agricultural Engineering and Environmental Management, College of Agriculture, Central Philippine University, Iloilo City, Philippines (2005): 1-155.

[10] Patra, Tapas Kumar, and Pratik N. Sheth. "Biomass gasification models for downdraft gasifier: A state-of-the-art review." Renewable and Sustainable Energy Reviews 50 (2015): 583-593.

https://doi.org/10.1016/i.rser.2015.05.012

[11] Susastriawan, A. A. P., and Harwin Saptoadi. "Small-scale downdraft gasifiers for biomass gasification: A review." Renewable and Sustainable Energy Reviews 76 (2017): 989-1003. https://doi.org/10.1016/i.rser.2017.03.112

[12] Susastriawan, A. A. P., Harwin Saptoadi, and Purnomo. "Design and experimental study of pilot scale throat-less downdraft gasifier fed by rice husk and wood sawdust." International Journal of Sustainable Energy 37, no. 9 (2018): 873-885. https://doi.org/10.1080/14786451.2017.1383992

[13] Guangul, Fiseha M., Shaharin A. Sulaiman, and Anita Ramli. "Gasifier selection, design and gasification of oil palm fronds with preheated and unheated gasifying air." Bioresource technology 126 (2012): 224-232. https://doi.org/10.1016/i.biortech.2012.09.018

[14] Zainal, Z. A., Ali Rifau, G. A. Quadir, and K. N. Seetharamu. "Experimental investigation of a downdraft biomass gasifier." Biomass and bioenergy 23, no. 4 (2002): 283-289. https://doi.org/10.1016/S0961-9534(02)00059-4

[15] Almeida, Ana, Paula Neto, Isabel Pereira, Albina Ribeiro, and Rosa Pilão. "Effect of temperature on the gasification of olive bagasse particles." Journal of the Energy Institute 92, no. 1 (2019): 153-160. https://doi.org/10.1016/i.joei.2017.10.012

[16] Isa, Kamariah Md, Kahar Osman, Nik Rosli Abdullah, Nor Fadzilah Othman, and Nurulnatisya Ahmad. "Coal Type, Temperature and Gasifiying Agent Effects on Low-Rank Coal Gasification Using CFD Method." CFD Letters 12, no. 10 (2020): 111-127. https://doi.org/10.37934/cfdl.12.10.111127 
[17] Khosasaeng, Trirat, and Ratchaphon Suntivarakorn. "Effect of equivalence ratio on an efficiency of single throat downdraft gasifier using RDF from municipal solid waste." Energy Procedia 138 (2017): 784-788. https://doi.org/10.1016/i.egypro.2017.10.066

[18] Upadhyay, Darshit S., Anil Kumar Sakhiya, Krunal Panchal, Amar H. Patel, and Rajesh N. Patel. "Effect of equivalence ratio on the performance of the downdraft gasifier-An experimental and modelling approach." Energy 168 (2019): 833-846.

https://doi.org/10.1016/i.energy.2018.11.133 